\title{
The Influence of Phytase Enzyme to Laying Performance and Quality of Egg Shell of Golden Arabian Chicken
}

\author{
Eli Sahara ${ }^{1, *}$, Feni Despedia ${ }^{1}$, and Raden Ayu Aminah ${ }^{1}$ \\ ${ }^{1}$ Department of Animal Science, Faculty of Agriculture, Universitas Sriwijaya, South Sumatra, 30662, \\ Indonesia
}

\begin{abstract}
Poultry has low ability to digest dietary fibre and to process phytate. Rice bran is intensively used in poultry ration although it contains little bit higher in fibre and phytate. The purpose of this study was to find out the optimal level of phytase the enzyme that could break down phytate in the ration of Golden Arabian chicken to increase performance and physical quality of the eggs. This study used 90 golden arabian chickens (Golden Brakel Kriel), approximately five months of age. Individual cage with a wire floor was equipped with a feed and drinking troughs. Experimental ration was with a mixture of corn, rice bran, commercial concentrate, and mineral mixture. Phytase was added at the level of: zerro, without phytase $=\mathrm{P} 1 ; 100 \mathrm{FTU} / \mathrm{kg}$ of ration; $200 \mathrm{FTU} / \mathrm{kgof}$ ration $=\mathrm{P} 2$; $300 \mathrm{FTU} / \mathrm{kg}$ of ration $=\mathrm{P} 3 ; 400 \mathrm{FTU} / \mathrm{kg}$ of ration $=\mathrm{P} 4$; and $500 \mathrm{FTU} / \mathrm{kg}$ of ration $=\mathrm{P} 5$. Experimental design that used in this study was Complete Randomized Design (CRD) with six treatments and five replications and three golden arabian chickens per experimental unit. Results showed that the addition of phytase in golden arabian chickens ration improved the hen day production $(\mathrm{P}<0.05)$ up to $71.43 \%$ and increased the physical quality, especially weight of eggshell significantly $(\mathrm{P}<0.05)$ up to 4.516 gram (phytase enzyme $300 \mathrm{FTU} / \mathrm{kg}$ ). In conclusion, that the level of the phytase of $300 \mathrm{FTU} / \mathrm{kg}$ of ration was the most optimal dose to increase the daily egg production and improve the physical quality. However, the addition of phytase did not affect to feed consumption, feed efficiency, eggshell thickness and eggshell thickness index.
\end{abstract}

\section{Introduction}

The quality of diets was assessed by its raw materials, the adequacy of nutritional value, digestibility and the digestibility of ration. Digestibility of feed intended to be absorbed by the body. Digestive system will work properly if the digestibility of feed is also good, so that feed nutrients to be absorbed properly by the body. The ability of livestock to absorb all the nutrients has positive impact to productivity of livestock. Poultry is known to have very poor ability to digest crude fibre. This is because poultry does not have the digestive enzymes for the crude fiber in their digestive systems such as cellulose and phytase [13].

Poultry diet provides $50 \%$ to $60 \%$ of energy from cereal crops such as corn and rice bran. According to Guenter [5], cereal crops contains a high phytic acid which causes some 
minerals and proteins into insoluble, so it is not absorbed by the intestinal of the nonruminant animals [9]. Phytic acid in the rice bran contains a high crude fibre, which limits the inclusion amount in poultry ration.

The productive laying hens requires a higher nutritional value especially adequate protein and minerals for maximum egg production. Production and the physical condition of egg such as weight and strength of egg shell are determinant of quality image in egg type of poultry. The benefits of phytase are digesting phytic acid, which bind available minerals ( $\mathrm{Mg}, \mathrm{Mn}, \mathrm{Fe}, \mathrm{Zn}, \mathrm{Ca}$ and $\mathrm{Cu}$ ) and protein. Cowieson et al.[2] reported that the addition of phytase to chicken diet had important influence to decrease endogenous amino acids flow, increase protein digestibility, amino acids and phosphorus as well as the availability of dietary energy. The phytase could even eliminate antinutrition (phytic acid) in the chicken feed. Ceylan et al [3] reported that the addition of phytase up to $300 \mathrm{FTU} / \mathrm{kg}$ feed could improve the feed utilization efficiency. The aim of the experiment was to find out the effect of additional phytase in the ration on production and quality of golden arabian chickens eggs (brakel kriel gold).

\section{Materials and Methods}

\subsection{Animal Experimentation}

This experimentation used 90 golden arabian chickens. The age of chickens was five months or less. Golden arabian chickens were confined in the individual cage equipped with feed and drinking troughs. Body weight of each chicken was taken at the beginning of the experimental period. Chickens were randomly inserted into the cage. Feed was given twice a day at 07.00 and 16.00.and drinking water was provided adlibitum.

\subsection{Addition of Phytase in Ration}

The ingredients of basal ration that used in the study were $49 \%$ of corn, $20 \%$ of rice bran, $30 \%$ of commercial concentrate and 1\% mineral mixture. Concentrate used a commercial concentrate was produced by PT Charoen Pokphand Indonesia, Banten. Nutritional content in this concentrate, respectively is $1,800 \mathrm{kcal} / \mathrm{kg} \mathrm{EM}, 32 \% \mathrm{PK}$, LK 3\%, $8 \%$ SK $10 \%$ CA and $1.10 \%$ P. Commercial phytase was produced by BASF chemical company, called as Natuphos $5000 \mathrm{G}$ in solid powder form. The way to mix phytase into basal ration was using method modified from Erbsloh [4]. The phytase was dissolved with a little bit water and then it was mixed well with rice bran and corn. The mixture was placed at room temperature for one hour to give time to the phytase reacting to the substrate. Then the mixture was mixed with commercial concentrate and mineral mixture. While, phytase was added to the basal ration following the level of: $\mathrm{P} 0=$ without the addition of the phytase; P1 = $100 \mathrm{FTU} / \mathrm{kg}$ feed; P2 = $200 \mathrm{FTU} / \mathrm{kg}$ feed; P3 = $300 \mathrm{FTU} / \mathrm{kg}$ feed; P4 = 400 FTU/ kg feed; and P5 = $500 \mathrm{FTU} / \mathrm{kg}$ feed.

\subsection{Experimentation Method and Data Analysis}

The measure variables were feed consumption, egg production, feed efficiency, egg weight, weight of egg shell, egg shell thickness, and egg shell thickness index. The experimental design was Completed Randomized Design (CRD) with 6 treatments, 5 replications and 3 golden arabian chicken per experimental unit [15]. Data was analysed by 
using ANOVA method followed by Duncan's test for testing the differences among the treatment mean values.

\section{Results and Discussions}

\subsection{Feed Consumption.}

The average of feed consumption during experimentation was ranged from 84.93 to $88.44 \mathrm{~g} / \mathrm{hen} /$ day. The statistical analysis results showed that the the effect of addition of phytase on feed consumption was highly significant $(\mathrm{P}<0.01)$. By adding phytase at a dose of $200 \mathrm{FTU} / \mathrm{kg}$ of diet gave the lowest feed consumption $84.93 \mathrm{~g} / \mathrm{hend} / \mathrm{day}$. This indicated that the additional of the phytase of $200 \mathrm{FTU} / \mathrm{kg}$ feed could accelerate nutrient metabolism. This indication was supported by [9], reported that the presence of phytic acid content caused some of the minerals and proteins into insoluble so it cannot be absorbed by poultry. It is suspected the addition of the enzyme phytase $200 \mathrm{FTU} / \mathrm{kg}$ ration more able to break the bond of phytic acid on nutrient ration so that the nutrients more available and more easily absorbed. Nutritional adequacy of treatment is considered more able optimize the body's physiological functions and provide energy for growth and production. Leeson and Summers [6], stated that if management factors are well controlled, the consumption of which depends on the nation's ration (breed) chicken, ambient temperature, the number of eggs produced mass and energy content of the ration. Ration consumption is mainly due to lower energy requirements enough so that with the addition of the enzyme phytase 200 FTU / kg to meet the energy needs of the chicken. Effect of the addition of phytase into the ration on performance and physical quality of egg shell of the arabian golden chicken are shown in Table 1.

Table 1. Effect of the addition of phytase into the ration on performance and physical quality of egg shell of the arabian golden chicken

\begin{tabular}{|c|c|c|c|c|c|c|c|}
\hline $\begin{array}{c}\text { Treat- } \\
\text { Ments }\end{array}$ & $\begin{array}{c}\text { Feed } \\
\text { Consumption } \\
\text { (g/hen/day) }\end{array}$ & $\begin{array}{c}\text { Hen Day } \\
\text { Production } \\
\mathbf{( \% )}\end{array}$ & $\begin{array}{c}\text { Egg } \\
\text { Weight } \\
\text { (gram) }\end{array}$ & $\begin{array}{c}\text { Feed } \\
\text { Efficiency } \\
\mathbf{( \% )}\end{array}$ & $\begin{array}{c}\text { Egg } \\
\text { Weight } \\
(\mathbf{g r a m})\end{array}$ & $\begin{array}{c}\text { Shell } \\
\text { Thickness } \\
(\mathbf{m m})\end{array}$ & $\begin{array}{c}\text { Shell } \\
\text { Index } \\
\left(\mathbf{g} / \mathbf{c m}^{\mathbf{2}}\right)\end{array}$ \\
\hline P0 & $88.44^{\mathrm{c}}$ & $60.79^{\mathrm{a}}$ & 40.61 & 45.96 & $4.523^{\mathrm{b}}$ & 0.404 & 8.325 \\
\hline P1 & $87.42^{\mathrm{c}}$ & $68.89^{\mathrm{b}}$ & 39.31 & 45.19 & $4.278^{\mathrm{ab}}$ & 0.398 & 8.097 \\
\hline P2 & $84.93^{\mathrm{a}}$ & $70.32^{\mathrm{b}}$ & 39.51 & 47.67 & $4.462^{\mathrm{ab}}$ & 0.388 & 7.937 \\
\hline P3 & $85.94^{\mathrm{ab}}$ & $71.43^{\mathrm{b}}$ & 40.08 & 47.01 & $4.516^{\mathrm{b}}$ & 0.409 & 8.422 \\
\hline P4 & $87.95^{\mathrm{c}}$ & $71.59^{\mathrm{b}}$ & 40.14 & 45.79 & $4.523^{\mathrm{b}}$ & 0.400 & 8.256 \\
\hline P5 & $86.91^{\mathrm{b}}$ & $70.95^{\mathrm{b}}$ & 40.27 & 46.33 & $4.534^{\mathrm{b}}$ & 0.411 & 8.467 \\
\hline
\end{tabular}

Note: Means with different superscript in each measured variable in the same column were significantly different $(\mathrm{P}<0.01)$. $\mathrm{P} 0=$ basal diet without giving the enzyme phytase; $\mathrm{P} 1=$ basal diet + phythase enzyme $100 \mathrm{FTU} / \mathrm{kg}$ diet; P2= basal diet + phythase enzyme $200 \mathrm{FTU} / \mathrm{kg}$ diet; $\mathrm{P} 3=$ basal diet + phythase enzyme $300 \mathrm{FTU} / \mathrm{kg}$ diet; P4= basal diet + phythase enzyme 400 FTU/kg diet; P5= basal diet + phythase enzyme $500 \mathrm{FTU} / \mathrm{kg}$ diet.

\subsection{Egg production}

There was a significant different in egg production between with and without the addition of phytase $(\mathrm{P}<0.05)$. This results showed that the phytase could accelerate metabolism of chicken body through the sufficiently available phosporus that was absorbed for energy and nutrient metabolism. The result was supported by [2] that the additional of the phytase could increase egg production. The main nutrients that need to be considered 
for the production of laying hens wasthe balance of protein and minerals, especially $\mathrm{Ca}$ and $\mathrm{P}$, corresponding to streng then egg shell. Thus, by the addition of phytase, it was assumed that improved the digestibility of feed. This indication was also supported by [9] that the addition of phytase could improve digestion of feed in laying hens providing not only $\mathrm{Ca}$ and $\mathrm{P}$, but also amino acids to be absorbed sufficiently for supporting maximum performance.

\subsection{Egg Weight}

The results showed that the addition of phytase in feed did not significantly influence the weight of the egg $(\mathrm{P}>0.05)$. It was assumed that the effects of phytase apparently focused on to metabolize the working of hormones as trigger to reproduce yolk in the ovarian. Availability of mineral valence 2 very helpful in fluency metabolism such as $\mathrm{Ca}$, $\mathrm{Zn}, \mathrm{P}$. Mc Dowell [10] stated that Zn deficiency can interfere with the development of sex organs and interfere with all phases of the process of reproduction in females. The mass of the ovary consists of egg yolks. Summiati [16] reported that the administration of the enzyme phytase 750 and $1000 \mathrm{FTU} / \mathrm{kg}$ ration proved to increase the rat ovarian weight $0.105 \%$ and $0.075 \%$ of the live weight. The increased weight of the ovary indicates the active role of estrogen and FSH stimulates the follicles in the ovaries. This indicates that there is a close connection with the active reproductive organ weights hormones work. The other thing, because of the golden arabian chickens that used in this experiment were in the first production phase, the eggs produced tended to be small. [1] stated that the weight of eggs produced in the early phase of production was smaller than in the next production phase.

\subsection{Feed Efficiency}

There were no differences in the efficiency of the feed utilization efficiency due to addition phytase in the ration $(\mathrm{P}>0.05)$. [12] stated that the efficiency of the conversion ratio is closely related to, and influenced by ration consumption, egg weight and egg production. Although there are significant differences in the consumption of rations but will not affect the weight of the egg. It is suspected the addition of the enzyme phytase in the ration having the same effect in helping the absorption of proteins and fats in the digestive tract, so that the resulting weight of the eggs are almost the same between treatments. Egg weight ratio similar to ration consumption did not provide significant efficiency rate variations.

\subsection{Eggshell Weight}

The further test results showed that the addition of phytase in diet, influenced significantly the thickness of golden arabian chicken egg shell $(\mathrm{P}<0.05)$. Average weight of shell obtained ranged from 4.24 to 4.53 grams. The increasing level of phytase from 300 to $500 \mathrm{FTU} / \mathrm{kg}$ increased shell weight $(4.516,4.523,4.534$ gram). There is a direct relationship between the weight of a thick shell with egg shell. Heavier egg shell followed by egg shell thickness with increasing doses of the treatment. This indicates that the organic matrix is crucial constituent of egg shell to shell weight. Egg shell is composed of crystals which occupies two-thirds of the entire shell. The crystals are placed in the organic matrix composed of protein and mucopolysaccharide [11]. Building blocks of the shell consist of organic matter $95.1 \%$, protein 3.3 and water $1.6 \%$ [19]. Most of the shells consisting of 
calcium carbonate $95 \%$ [18] and the improvement of its formation occurs in the uterus which takes about 20 hours. The greater the dose of phytase enzyme in this study indicates an increase in shell weight as a reflection of phytase enzymes to facilitate the awarding body's metabolism, including the availability of organic matter and calcium carbonate as the main filler egg shell.

\subsection{Egg shell thickness}

The addition of phytase in diet did not influence the thickness of golden arabian chicken egg shell.. In this experiment, the average of egg shell thickness ranged from 0.388 to 0.411 $\mathrm{mm}$. However, the shell thickness in this experiment was greater than the argumentation of [12], that egg shell thickness was ranged 0.33 to $0.35 \mathrm{~mm}$ and larger than the egg shell thickness from [8], which showed that the egg shell thickness of ISA Brown fed with calcium content of $4.0 \%$ and $0.25 \%$ available phosphorus with phytase supplementation of $300 \mathrm{U} / \mathrm{kg}$ of diet was increased to $0.358 \mathrm{~mm}$. Although the addition of phytase did not affect the egg shell thickness, but in terms of physical quality of eggs, had been giving out a significant contribution to the increased weight of the egg shell as dose of feed of 300-500 FTU / kg of diet.

\subsection{Egg Shell- Thickness Index}

The result showed that the addition of phytase in diet did not influence significantly $(\mathrm{P}>0.05)$ the egg shell-thickness index of golden arabian chicken. The average index of egg shell thickness of golden arabian chicken during the experiment ranged from 7.937 to 8.467 $\mathrm{g} / \mathrm{cm}^{2}$. [7] reported that the egg shell-thickness index was about 7.91 to $8.26 \mathrm{~g} / \mathrm{cm}^{2}$. However, [17] stated diffently, that eggshell thickness index was about 7.60 to $7.93 \mathrm{~g} / \mathrm{cm}^{2}$. Average egg shell thickness index has a similar diversity. It is suspected closely associated with the average egg weight were also similar. Thus it can be said that the addition of phytase affected to quality of the egg shell of golden arabian chicken. Intended purposes, the addition of the phytase enzyme reduce feed consumption and improve productivity [2]. It was concluded that the addition of phytase enzyme of $300 \mathrm{FTU} / \mathrm{kg}$ of diet was the best treatment in this experiment.

\section{Conclusions}

Results of the experiment showed that the addition of phytase in golden arabian chickens diet could improve significantly, the egg production $(\mathrm{P}<0.05), 60.79 \%$ to $71.43 \%$ and increased weight of egg shell, $(\mathrm{P}<0.05), 4.278$ gram to 4.516 gram. In conclusion, the addition of the phytase of $300 \mathrm{FTU} / \mathrm{kg}$ feed in the diet was the most optimal level to increase the hen day production and improve the physical quality. However, the addition of phytase in dietary treatment did not give effect to the feed consumption, feed efficiency, egg shell thickness and egg shell thickness index.

\section{References}

1. Amrullah, I.K, Layer Chicken Nutrition.Institute of Satu Gunungbudi (Kompleksof IPB, Baranangsiang, Bogor, 2003)

2. Cowieson A. J, V. Ravindran, \& P. H. Selle. J. Poultry Sci 87 (2008) 
3. Ceylan, S. E., Scheideler,\& H. L. J. Poultry Sci 82 (2003)

4. Erbsloh Geisenheim AG. Phytase 5000. www.erbsloeh.com. Accessed on 20 Maret 2012 (2016)

5. Guenter W, Phytase in cereals and hemicelluloses in canola (repeseed) meal and lupins (Department of Animal science, University of Manitoba, Kanada, 2005)

6. Leeson, S.\& Summers J.D, Nutrition of the Chicken. Ed ke-4 (Guelph, Ontario: University Books, 2001)

7. Keshavarz, K. J. Poultry Sci 79 (2000)

8. Lim, H.S., Namkung H., \& Paik I.K. J. Poultry Sci 82

9. Liu, N, G. H. Liu, F. D. Li, J. S. Sands, S. Zhang, A. J. Zheng \& Y. J. Ru. J. Poult Sci 86 (2007)

10. McDowell, L.R. Mineral $s$ in Animal and Human Nutrition (Academic Press, Inc, London, 1992)

11. Nys, Y. and T. Yuwanta. Relationship between egg quality of dwarf breeder hens and growth and bone ossification of the offspring. Proc. $4^{\text {th }}$ European Symposium on Eggs and Egg Products (Doorwerth. Netherland, 1991)

12. North, M.O.\& Bell D.D. Commercial Chicken Production Manual, 4 th Ed (Van Nestrand Reinhold, New York, 1990)

13. Parsons, C.M. Gastrointestinal Development And Nutrient Digestion In Chicks, in: Proceedings of the 25th Western Nutrition Conference (2004)

14. Stadelman, W. J \& Owen J.C. Egg quality. Editors. Egg Science and Technology (3 ${ }^{\text {rd }}$. Westport, CT:AVI Publishing, 1986)

15. Steel, R.G.D \& Torrie J. H, Statistical Principle and Procedure. A biometrical approach (Sumantri. PT. Gramedia, Jakarta, Indonesia, 1991)

16. Sumiati. The Molar ratio of fitat Acid: $: z n$ to determine supplements $z$ and additional enzyme fitase in rations water acid fitat high. Doctor thesis (Graduated school, Bogor Agricultural University, Bogor, Indonesia, 2005)

17. Van der Klis, J.D, Versteegh H.A.J, Simons P.C.M \& Kies A.K. J. Poult Sci 76 (1997).

18. Wahju, J. Poultry Nutrition (Gadjah Mada University Press, Yogyakarta, Indonesia, 2004)

19. Winarno, F.G. and S Koswara. Egg: composition, handling, and processing (M-Brio Press, Bogor, Indonesia, 2002) 